\title{
Exploitation of Aspergillus niger for the Heterologous Production of Cellulases and Hemicellulases
}

\author{
S.H. Rose and W.H. van Zyl* \\ Department of Microbiology, University of Stellenbosch, Stellenbosch 7600, South Africa
}

\begin{abstract}
Filamentous fungi of the Aspergillus niger group are native soil saprophytic fungi. Industrial strains of this group have been extensively used for the production of plant degrading enzymes for the food and beverage, animal feed and paper-and-pulp industries. Recombinant DNA technology allows for the overproduction of these enzymes in copious amounts. The advantages and limitations of A. niger as recombinant host for enzyme production are briefly discussed. Specific attention is devoted to the overproduction of several cellulases and hemicellulases to high homogeneity in the protease-deficient strain A. niger D15. The size, temperature and $\mathrm{pH}$ optima of the heterologous enzymes were shown to be similar to that of their natively produced counter parts. The optimization of enzyme production in dilute sugar cane molasses, using a recombinant strain producing the xylanase II of Trichoderma reesei as example, was also demonstrated.
\end{abstract}

Key Words: Aspergillus niger, heterologous expression, cellulase, xylanase, mannanase.

\section{INTRODUCTION}

Filamentous fungi belonging to the genus Aspergillus are commonly associated with biomass degradation and produce a wide range of secreted hydrolases, including native endoand exo-acting enzymes involved in the degradation of plant cell walls. Detailed overviews of these enzymes, their characteristics and the regulatory systems involved for their production have been presented by Aro et al. [1], De Vries [2] and De Vries and Visser [3]. Strains of particularly the black aspergilli (Aspergillus niger group including well-known industrial strains of A. niger, Aspergillus aculeatus, and Aspergillus awamori) [4] have been used successfully as industrial host for the production of various plant cell wall degrading enzymes with cost-effective applications in the food and beverage, animal feed and paper-and-pulp industries [2]. Specific features that favour Aspergillus spp. for the production of industrial enzymes include its high secretion capacity, GRAS (Generally Regarded $\underline{\text { As }} \underline{\mathrm{S}} \mathrm{S}$ e) status, rapid growth on inexpensive media and the large range of native enzymes produced. These features render Aspergillus spp. ideal for commodity enzyme applications on inexpensive media, however, the concomitant production of a large variety of native enzymes by host strains, together with the production of undesirable proteases, limit the large scale production of single enzymes or enzyme cocktails for specific applications.

During the past two decades much progress has been made towards the development of Aspergillus spp. as host for the production of heterologous proteins in concentrations of up to grams per liter [5-8]. Aspergillus has been established as efficient host for the production of a variety of enzymes, including proteases, lipases, phytases, numerous glycosyl hydrolases, as well as pharmaceuticals [9-12]. Although Aspergillus spp. have much to offer as recombinant

*Address correspondence to this author at the Department of Microbiology, University of Stellenbosch, Stellenbosch 7600, South Africa;

E-mail:WHVZ@sun.ac.za hosts, several limitations still hampers its optimum use for recombinant protein production. The production of proteases is one of the major hurdles, more so for heterologous than for homologous proteins [8]. Aspergillus spp. can produce a range of diverse proteases, of which the acid proteases predominate since medium acidification normally occurs during cultivation. Approaches taken to limit protease production include medium optimization, classical mutagenesis to generate protease-deficient strains or $\mathrm{pH}$ mutants with decrease protease production, and selective disruption of protease genes on the genome [13].

Being natural plant degraders, Aspergillus spp. produce a large variety of cellulases and hemicellulases, when cultivated on plant polysaccharides [3]. Enzyme cocktails are routinely used for industrial applications in the technical, food and feed enzyme markets, but the purification of specific enzyme activities from cellulase and hemicellulase mixtures remains costly and time-consuming. Furthermore, the production of cellulases and hemicellulases are subject to transcriptional activation via $\mathrm{X} \ln \mathrm{R}$ in the presence of lignocellulosics, carbon catabolite repression in the presence of simple sugars mediated by CreA and induction under nitrogen-limiting conditions by AreA [1]. Carbon catabolite repression is especially problematic for large scale production of enzymes on inexpensive cultivation medium (such as cane and sugar beet molasses) that contains easily metabolised sugars as carbon source.

Plant cell wall degrading enzymes have a broad spectrum of industrial applications with a world market estimated to grow to $\$ 2$ billion by [14]. The largest group (about $65 \%$ ) is technical enzymes used in the detergent, textile, leather and pulp and paper industry, second by food enzymes (about $27 \%$ ), followed by enzymes used in the animal feed industry (about 6\%) [2, 3, 15-19]. Xylanases found applications in the baking industry by modifying cereal flours [20], improvement in the nutritional value of animal feeds for ruminants (cattle and sheep) [21] and monogastrics (chickens and pigs) 
[22, 23], and the pre-bleaching of pulp for paper making [24]. Xylanases and cellulases (together with pectinases) are used for the clarification of wine and fruit juice [25], liquefying of fruits and vegetables for the making of puree and the treatment of textiles [26, 14]. More than three-quarter of the enzymes are hydrolases produced by filamentous fungi (particularly Aspergillus spp.). Industrial scale enzyme production by fungi accounts for more than $40 \%$ of the commercial enzyme market $[14,27]$. The saccharification of plant biomass for the production of fuel ethanol has the potential of outgrowing all three these markets, taking enzymes applications in the industrial biotechnology era to new heights [28]. With the recent development of cost-effective lignocellulosic enzyme mixtures, cellulases and hemicellulases will enter the major biofuel markets for the efficient enzymatic conversion of plant biomass to fermentable sugars for bioethanol production [28].

Currently, the production of specific cellulase and hemicellulase activities to high homogeneity without additional native enzyme activities from wild-type strains of Aspergillus, remains a challenge. In this study we constructed genetically engineered strains of $A$. niger to constitutively overproduce different hydrolases to address the problem of ho- mogeneity. The production of cost-effective hydrolases requires the use of inexpensive cultivation medium such as molasses based medium. Whereas growth and production of primary metabolites on molasses based industrial medium has been reported in literature [29, 30], few studies have considered production of recombinant proteins on such medium. Therefore, we also explored the impact of cultivation conditions and strain properties on growth and production of recombinant Xyn $2 \beta$-xylanase produced by A. niger D15 in a medium consisting solely of diluted molasses (diluted to $20 \%$ molasses in water).

\section{MATERIALS AND METHODOLOGY}

\section{Strains, Plasmids, Media and Cultivation Conditions}

The genotypes of the bacterial and fungal strains as well as the plasmids used in this study are summarized in Table $\mathbf{1 .}$ The construction of the plasmids and the fungal strains was similar to that described in detail in Rose and van Zyl (2002) [31]. The plasmid, pBS-pyrGamdS, was introduced and integrated into the genomes of A. niger D15[pGT] and A. niger D15[xyn2], resulting in the prototrophic A. niger D15[pGT] $\mathrm{PyrG}^{+}$and $A$. niger D15[xyn2]PyrG ${ }^{+}$strains (Table 1). The

Table 1. The Genotype and Sources of the Strains and Plasmids Used in this Study

\begin{tabular}{|c|c|c|}
\hline A. niger $\mathrm{D} 15^{\mathrm{a}}$ & pyrG prtT phmA & - \\
\hline A. niger $\mathrm{D} 15[$ manl] & A. niger $\mathrm{D} 15$ with $\operatorname{gpd}_{P^{-}-\mathrm{man} 1-\text { glaA }_{T} \text { integrated into genome }}$ & Aspergillus aculeatus \\
\hline A. niger $\mathrm{D} 15[$ acegI] & A. niger $\mathrm{D} 15$ with $\operatorname{gpd}_{P}$-acegI-glaA $A_{T}$ integrated into genome & Aspergillus carneus \\
\hline A. niger $\mathrm{D} 15[\text { eg } 1]^{\mathrm{b}}$ & A. niger D15 with gpd $_{P}$-eg1-gla $A_{T}$ integrated into genome & Trichoderma reesei \\
\hline A. niger $\mathrm{D} 15[$ eg2] & A. niger D15 with $g p d_{P}$-eg2-gla $A_{T}$ integrated into genome & T. reesei \\
\hline A. niger $\mathrm{D} 15[x y n 2]^{\mathrm{b}}$ & A. niger D15 with gpd $_{P}$-xyn2-glaA $A_{T}$ integrated into genome & T. reesei \\
\hline Plasmids: & & Gene Product \\
\hline $\mathrm{pGT}^{\mathrm{b}}$ & bla gpd $_{P^{-}}$gla $_{T}$ & - \\
\hline pBS-pyrGamdS ${ }^{c}$ & bla pyrG amdS & PyrG \& AmdS \\
\hline pGT-manI & bla gpd $_{P}-\operatorname{man} 1-$ glaA $_{T}$ & ManI \\
\hline pGT-acegI & bla gpd $d_{P}$-acegI-glaA $A_{T}$ & AcegI \\
\hline pGT-eglA & bla gpd $_{P}-$ eglA-glaA $A_{T}$ & EglA \\
\hline pGT-eg $1^{\mathrm{b}}$ & bla gpd $_{P^{-}}$eg1-glaA $A_{T}$ & $\mathrm{EgI}$ \\
\hline
\end{tabular}

${ }^{\mathrm{a}}[33],{ }^{\mathrm{b}}[31],{ }^{\mathrm{c}}[34]$. 
procedure for salt adaptation was followed as described in Redkar et al. (1998) [32]. The fungus was plated out twice onto spore plates containing $0.5 \mathrm{M} \mathrm{KCl}$ and allowed to grow and sporulate for 4 - 6 days. The spores were subsequently transferred to plates containing $1 \mathrm{M}, 1.5 \mathrm{M}$ and $2 \mathrm{M} \mathrm{KCl}$. Finally, spores were transferred three times to plates containing $2 \mathrm{M} \mathrm{KCl}$. Spores of the salt adapted strains of A. niger D15[pGT]PyrG ${ }^{+}$and A. niger D15[xyn2] $\mathrm{PyrG}^{+}$, subsequently called A. niger D15[pGT]SA and A. niger D15[xyn2]SA, respectively, were stored in a $2 \mathrm{M} \mathrm{KCl}$ solution. Strains were inoculated to a final concentration of $1 \times 10^{6}$ spores $/ \mathrm{ml}$ in 2xMM [31] unless stated otherwise. Cultivation took place at $30^{\circ} \mathrm{C}$, in $125 \mathrm{ml}$ flasks containing $20 \mathrm{ml}$ medium, with aeration (mixing) at $100 \mathrm{rpm}$.

\section{Optimisation of Molasses as Cultivation Medium}

The molasses used in this study was supplied by Tongaat-Hulett (South Africa). Routinely, $20 \mathrm{ml}$ of $20 \%$ molasses (native $\mathrm{pH}$ of 5.5) was inoculated to a final concentration of $1 \times 10^{5}$ spores per $\mathrm{ml}$, cultivated at the above mentioned conditions. Although the A. niger D15[xyn2] and A. niger $\mathrm{D} 15[\mathrm{pGT}]$ strains require uridine for growth in synthetic media, they grow well in molasses without the addition of uridine and uridine was subsequently omitted from the media. The optimal concentration of the molasses required for optimal Xyn2 production, was determined by using flasks containing $20 \mathrm{ml}$ of $10,20,30,40$ and $50 \%$ molasses (v/v) inoculated with $1 \times 10^{5}$ spores/ml of the A. niger D15[pGT] and A. niger D15[xyn2] strains, respectively. The ideal inoculum concentration of $A$. niger D15[pGT] and A.niger D15[xyn2] spores was determined by inoculating $20 \mathrm{ml}$ of $20 \%$ molasses, to a final concentration of $1 \times 10^{4}, 1 \times 10^{5}$ and $1 \times 10^{6}$ spores per $\mathrm{ml}$, respectively. The optimal temperature of cultivation was determined by inoculating $1 \times 10^{5}$ spores/ $\mathrm{ml}$ of A. niger D15[pGT] and A. niger D15[xyn2] in $20 \mathrm{ml}$ of $20 \%$ molasses and cultivating at 20,25 and $30^{\circ} \mathrm{C}$, respectively. The optimum $\mathrm{pH}$ required for the germination of the spores was determined by inoculating $1 \times 10^{5}$ spores $/ \mathrm{ml}$ of the A. niger D15[pGT] and A. niger D15[xyn2] strains in $20 \mathrm{ml}$ of $20 \%$ molasses. The initial $\mathrm{pH}$ of the molasses was set at $\mathrm{pH} 5.5,6.5,7.5$ and 8.5 by the addition of $10 \mathrm{M} \mathrm{NaOH}$ aseptically after autoclaving.

The A. niger D15[pGT], A. niger D15[xyn2] and A. niger $\mathrm{D} 15[x y n 2] \mathrm{PyrG}^{+}$strains were inoculated to a spore concentration of $1 \times 10^{6}$ spores $/ \mathrm{ml}$ in $20 \mathrm{ml}$ of $20 \%$ molasses at $\mathrm{pH}$ 6.5 and cultivated under optimal conditions in order to determine if the uridine dependency of A. niger D15[xyn2] plays a significant role in the $\beta$-xylanase activity or biomass production. The salt adapted strain A. niger D15[xyn2]SA was compared to A. niger D15[xyn2] $\mathrm{PyrG}^{+}$(which was not salt adapted) by inoculating and cultivating them under optimal conditions to determine whether the salt adaptation had any effect on the amount of $\beta$-xylanase activity produced.

\section{Enzyme Assays}

The recombinant strains were cultivated in shake flasks containing $2 \mathrm{xMM}$ [31] and the extracellular production of the heterologous enzymes monitored over a period of 10 days. Individual recombinant enzymes were determined using $1 \% \mathrm{CMC}$ (carboxymethyl cellulose) as substrate for the $\beta$-endoglucanases, $1 \%$ birchwood xylan for the $\beta$-xylanases and $1 \%$ locust bean gum for the $\beta$-mannanase. The reducing sugars released from these substrates where determined with the dinitrosalicylic acid method $[35,36]$. The $\mathrm{pH}$ and temperature optima of the individual recombinant enzymes were also determined (Fig. 1a-d). One unit of enzyme was defined as the activity producing $1 \mu \mathrm{mol}$ per minute of reducing sugars in xylose equivalents under these assay conditions.

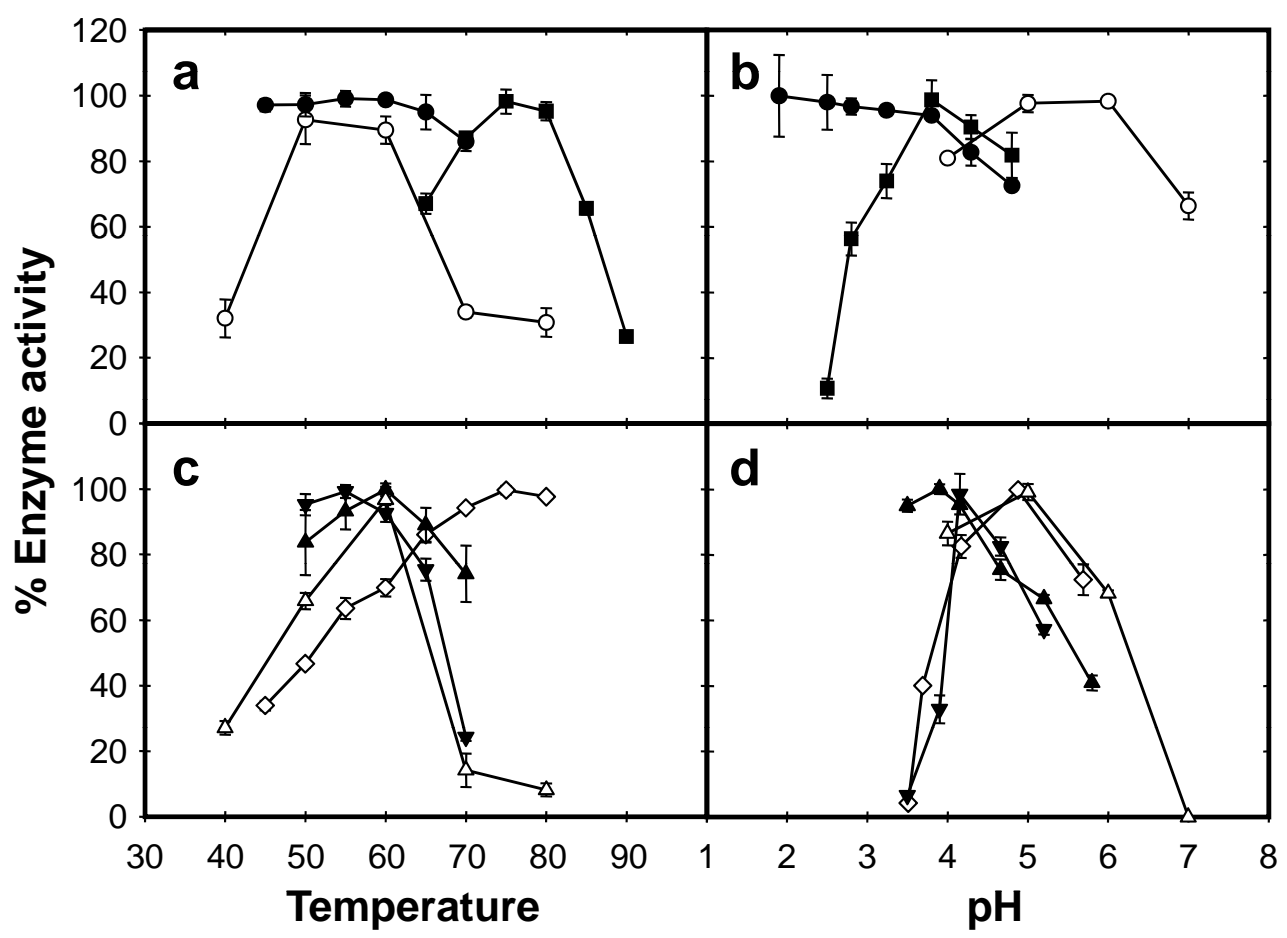

Fig. (1). The effect of (a and c) temperature and (b and d) pH on the enzymatic activity of the heterologous enzymes (ManI ( $\mathbf{\square})$, xynC ( $)$, EglA $(\boldsymbol{\Delta})$, AcegI $(\boldsymbol{\nabla})$ from Aspergillus species, and Xyn2 $(\bigcirc)$, TregI $(\triangle)$ and TregII $(\diamond)$ from T. reesei) when produced by A. niger D15. The enzymatic assays were performed in triplicate with the error bars indicating the deviation between the different samples. 


\section{RESULTS AND DISCUSSION}

\section{Selective Production of Cellulases and Hemicellulases by Recombinant $A$. niger Strains}

The strain A. niger D15 have previously proven to be an excellent host for the production of heterologous proteins [31]. Strain A. niger D15 was derived through successive mutagenesis events from the industrial strain N402 (ATCC 9029). Strain AB4.1, a cspAl pyrGl derivative of A. niger $\mathrm{N} 402$ [37], was subjected to UV mutagenesis and a proteasedeficient mutant AB1.13 obtained that produced only 1-2\% of the intracellular protease activity observed in the parental strain, AB4.1 [38]. The A. niger D15 strain was finally isolated as a non-acidifying, protease-deficient ( $p r t T)$ strain of $\mathrm{AB} 1.13[11,33,39]$. These characteristics enable the fungus to produce large quantities of protein with diminished degradation by natively produced acid proteases.

The construction of a successful expression system has previously been described in Rose and van Zyl [31] where the $\beta$-1,4-xylanase 2 (xyn2) and $\beta$-1,4-endoglucanase I (egI) genes of Trichoderma reese $i$ were successfully expressed in A. niger D15 under the transcriptional control of the glyceraldehyde-6-phosphate dehydrogenase ( $g p d A$ ) promoter from A. niger and the glaA terminator of A. awamori. The strong glycolytic promoter was chosen to enable heterologous expression of individual cellulase and hemicellulase genes in A. niger D15 using simple fermentable sugars with limited production of the native hydrolases and proteases. Using the same expression system, several other cellulases and hemicellulases have also been overproduced in the laboratory strain of A. niger D15. These genes include the $\beta-1,4$-endoglucanase A (eglA) of A. niger, $\beta-1,4$-endoglucanase I (acegI) of Aspergillus cardeus, $\beta$-1,4-xylanase (xynC) of Aspergillus kawachii, the $\beta-1,4-$ mannanase (manI) of A. aculeatus, as well as the $\beta-1,4-$ endoglucanase II (eg2) of $T$. reesei. The genes were cloned with their native secretion signals intact, leading to the successful secretion of all the heterologous enzymes. Protein secretion was preferred to simplify downstream processing [27].

In most cases, with the exception of the $\beta$-mannanase I, the characteristics of the heterologous enzymes were similar to that of their natively produced counter parts (Table 2). In all cases the levels of activity expressed in A. niger was significantly higher than that produced by the native host or by recombinant S. cerevisiae (Fig. 2a,b). With the exception of the $\beta$-endoglucanase I of $T$. reesei [31], there was little evidence of overglycosylation (data not shown), which is normally associated with foreign gene expression in S. cerevisiae $[40,41]$.

\section{Submerged Cultivation on Simple Sugar Syrup (Molas- ses) as Substrate}

The product yield, production cost, and the cost of the feedstock in particular, are critically important determinants of the economical viability of applying these enzymes in industrial processes [53]. It is, therefore, important to produce enzymes from inexpensive and readily available substrates, in order to keep the production cost to a minimum. Since South Africa is a prominent producer of cane sugar, it was fitting to investigate the possible use of molasses C (a major by-product of the sugar cane industry) as carbon source. Molasses $\mathrm{C}$ is the condensed residue that remains after repeated removal of crystallized sucrose from the concentrated sugar juice. Molasses $\mathrm{C}$ is a heterogeneous product, containing approximately $46.7 \%$ total sugars of which $33.2 \%$ is sucrose, $2.1 \%$ chlorine, $3.3 \%$ potassium, with a variety of amino acids and spore elements [54]. It is readily available at low cost and used extensively in the manufacturing of bakers' yeast, in the fermentation industry for the production of potable alcohol and fuel alcohol, as well as the production of citric acid by A. niger [55].

The $\beta$-xylanase activity of recombinant A.niger D15 [xyn2]pyrG ${ }^{-}$was monitored over a period of 10 days under different cultivation conditions to determine the optimum conditions required for extracellular Xyn2 production in molasses media. The total biomass production (dry weight) after 10-day incubation periods was measured to determine the specific productivity (enzyme yield per biomass). The highest xylanase activities of 226 and $209 \mathrm{U} / \mathrm{ml}$ were produced in 20 and 30\% molasses, respectively (Fig. 3a), suggesting it being the preferred concentration for optimal enzyme production. Higher molasses concentrations sustained more biomass production, but less enzyme production. The maximum biomass $(58.4 \mathrm{~g} / \mathrm{l})$ was obtained at $40 \%$ molasses, but drastically declined at $50 \%$ with growth being visibly slower at this concentration (Table 3 ). The viscosity at $50 \%$ molasses limited agitation in shake flasks and most probably did not allow for efficient oxygen transfer. Molasses also contains a variety of components, some (such as heavy metals present) of which could be inhibitory. The $\beta$-xylanase production by A. niger D15[pGT] in all the experiments did not exceed $29 \mathrm{U} / \mathrm{ml}$ and was not included in Fig. (3a-d).

An increase in spore inoculums concentration from $1 \times 10^{4}$ spores $/ \mathrm{ml}$ to $1 \times 10^{5}$ spores $/ \mathrm{ml}$ and $1 \times 10^{6}$ spores $/ \mathrm{ml}$ gave 10 and $18 \%$ higher levels of heterologous $\beta$-xylanase production, respectively, however the biomass yields only increased slightly (Table 3). Protein secretion in filamentous fungi is believed to predominantly take place at the hyphal tips where proteins can pass through the newly synthesised cell wall $[27,56]$. The secretion capacity of a fungus is thus directly proportional to the number of hyphal tips present in the culture $[38,57]$. Higher spore concentrations yield more germinating spores, thus more individual mycelial masses with more hyphal tips form. The total biomass (dry weight, DW) yields were dependent on the utilizable sugars in the medium and did not increase significantly. We conclude that higher concentrations $\left(1 \times 10^{6}\right.$ spores $)$ are preferred for high heterologous $\beta$-xylanase production per biomass produced.

The efficiency of Aspergillus spore germination, the proteolytic system and morphology (pellet formation) were found to be affected by the $\mathrm{pH}$ of the growth media [11]. The optimum $\mathrm{pH}$ for spore germination was between $\mathrm{pH} 7-8$, whereas the natural $\mathrm{pH}$ of molasses is 5.5. Yet, the effect of $\mathrm{pH}$ at the time of inoculation was found to be less critical when considering both enzyme and biomass production (Table 3). The effect of cultivating at different temperatures on the heterologous production of $\beta$-xylanase was determined since MacKenzie et al. [57] found that lowering the cultivation temperature decreased biomass production, while increasing enzyme production. A temperature of $30^{\circ} \mathrm{C}$ yielded the highest $\beta$-xylanase production and productivity in the shortest time period (Fig. 3b, Table 3). Cultivation at lower 
Table 2. Comparison of the Enzyme Characteristics when Produced by Different Hosts

\begin{tabular}{|c|c|c|c|}
\hline \multicolumn{4}{|l|}{ AcegI } \\
\hline pH optimum & nd & nd & 4.2 \\
\hline Temp. optimum ${ }^{\circ} \mathrm{C}$ & nd & nd & 55 \\
\hline \multicolumn{4}{|l|}{$\operatorname{AnegA}$} \\
\hline Activity (U/ml) & nd & nd & 179.96 \\
\hline pH optimum & nd & nd & 3.8 \\
\hline Temp. optimum ${ }^{\circ} \mathrm{C}$ & nd & nd & 60 \\
\hline activity $(\mathrm{U} / \mathrm{ml})$ & $88.15\left[42^{\mathrm{a}}\right]$ & $7.14^{\mathrm{b}}$ & 137.97 \\
\hline pH optimum & $4-5[43,44]$ & $6[44]$ & $5\left[4^{\mathrm{c}}\right.$ in 43$]$ \\
\hline Temp. optimum ${ }^{\circ} \mathrm{C}$ & $60^{\circ} \mathrm{C}[44]$ & $60[44]$ & 60 \\
\hline Protein size $(\mathrm{kDa})$ & $50[43,45]$ & $60-100[43]$ & $62-100\left[67^{c}\right.$ in 43$]$ \\
\hline \multicolumn{4}{|l|}{ TregII } \\
\hline Activity (U/ml) & $11.2 \mathrm{U} / \mathrm{mg}[46]$ & $0.02[46]$ & 380.14 \\
\hline pH optimum & nd & $6^{\mathrm{d}}[46]$ & 4.8 \\
\hline Temp. optimum ${ }^{\circ} \mathrm{C}$ & nd & $50^{\mathrm{d}}[46]$ & 76 \\
\hline \multicolumn{4}{|l|}{ ManI } \\
\hline Protein size (kDa) & $45[41]$ & $50[41]$ & $45-50$ \\
\hline \multicolumn{4}{|l|}{ XynII } \\
\hline Activity (U/ml) & $323.94\left[47^{\mathrm{e}}\right]$ & $7198[40]$ & 485.9 \\
\hline pH optimum & $5-5.5[48]$ & $6[40]$ & $5-6$ \\
\hline Temp. optimum ${ }^{\circ} \mathrm{C}$ & $56-60^{\mathrm{e}}[49]$ & $60[40]$ & $50-60$ \\
\hline Protein Size (kDa) & $20[50]$ & $27[40]$ & 21 \\
\hline \multicolumn{4}{|l|}{ XynC } \\
\hline Activity (U/ml) & nd & $18[51]$ & 55.78 \\
\hline pH optimum & nd & $<3[51,52]$ & $<3$ \\
\hline Temp. optimum ${ }^{\circ} \mathrm{C}$ & nd & $60[51]$ & $55-60$ \\
\hline Protein size $(\mathrm{kDa})$ & $\begin{array}{c}19.8 \text { (theoretical) } \\
29 \text { (glycosylated) [52] }\end{array}$ & $24.5[51]$ & 22 \\
\hline
\end{tabular}

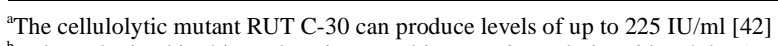

${ }^{\mathrm{b}}$ Values obtained in this study using a multicopy episomal plasmid and the $A D H 2$ promoter for expression in $\mathrm{SC}^{\text {-URA }}$ medium [40]

${ }^{c}$ Expression in Aspergillus oryzae as host

nd - not determined (no information available)

dassays were performed at conditions mentioned, but were not determined to be the optimal conditions.

${ }^{\mathrm{e}}$ The combined action of all the xylanases produced by $T$. reesei. 


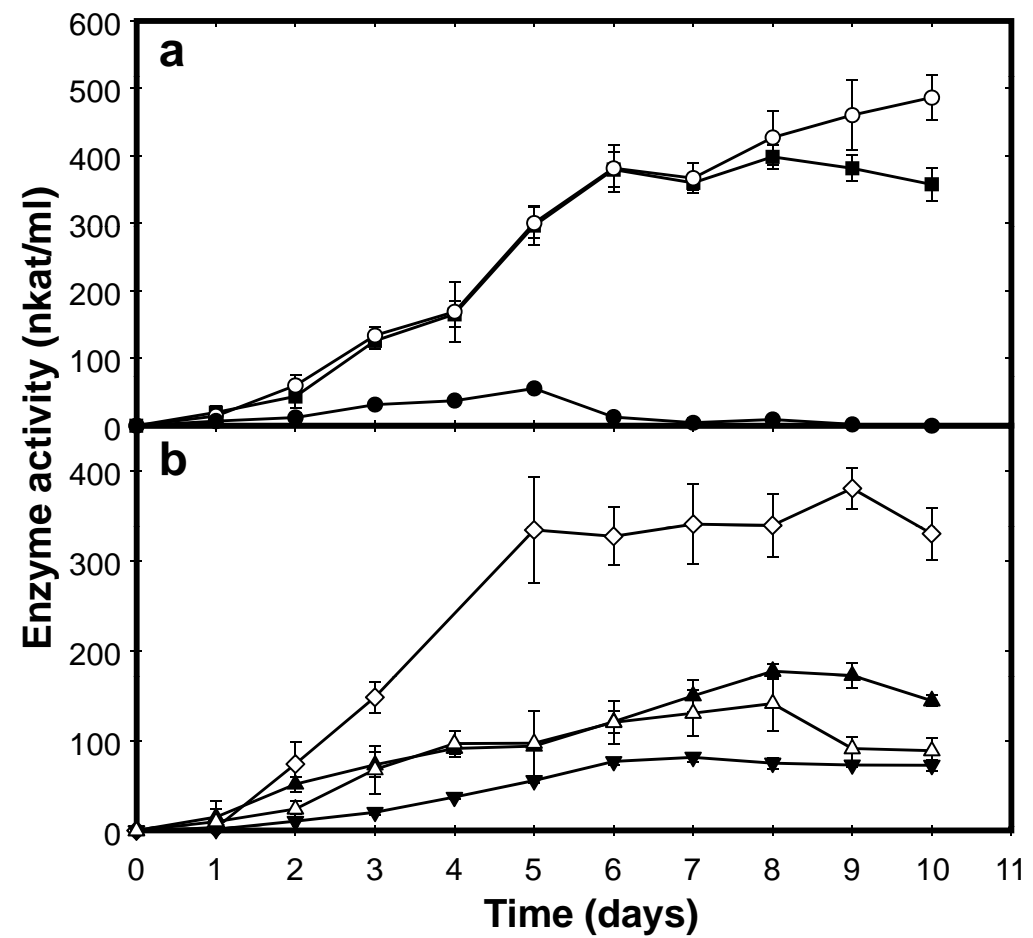

Fig. (2). The heterologous production of (a) hemicellulases and (b) endoglucanases by recombinant $A$. niger D15 strains. The production of ManI $(\boldsymbol{\square})$ of A. aculeatus, xynC $(\bullet)$ of A. kawachii, EglA $(\boldsymbol{\Delta})$ of A. niger, AcegI $(\boldsymbol{\nabla})$ of A. carneus, and Xyn2 $(\bigcirc)$, TregI $(\triangle)$ and TregII $(\diamond)$ of $T$. reesei was monitored over a period of 10 days in 2xMM medium. The values in this figure were obtained using six parallel cultures with the error bars indicating the deviation between the different flasks.
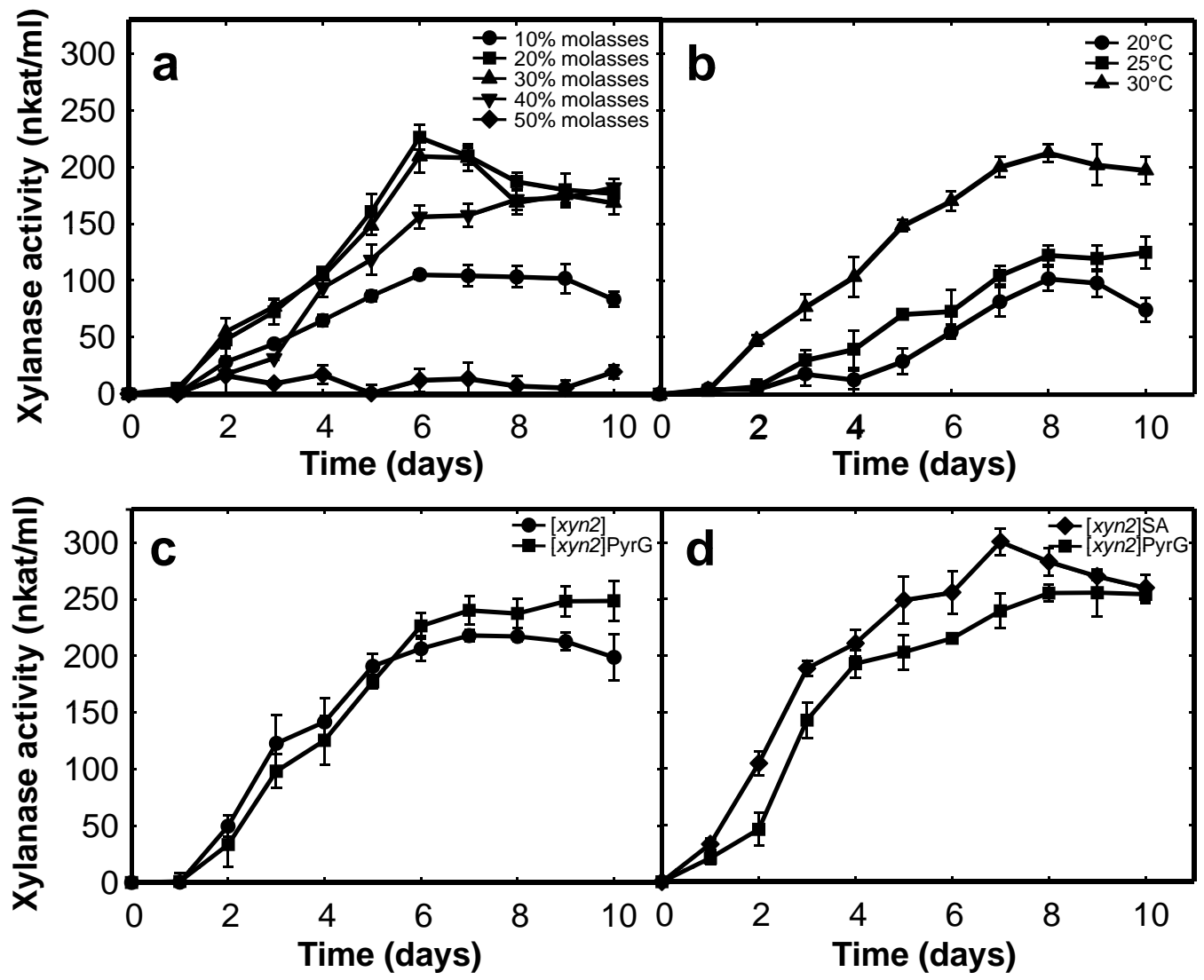

Fig. (3). The heterologous production of Xyn2 by recombinant A. niger D15 strains was monitored over a period of ten days in different molasses media formulation and under different growth conditions: (a) media formulations containing 10-50\% molasses concentration, (b) cultivation temperatures ranging from $20^{\circ} \mathrm{C}-30^{\circ} \mathrm{C},(\mathbf{c})$ introduction of additional pyrG gene copies and (d) salt adaptation to $2 \mathrm{M} \mathrm{KCL}$. The values in this figure were obtained using six parallel cultures with the error bars indicating the deviation between the different flasks. 
Table 3. The Maximum $\beta$-Xylanase Activity (U/ml), Total Biomass (g/L) and $\beta$-Xylanase Productivity (U/g) Recombinant $A$. niger Cultures were Determined after Cultivation of 10 Days in Different Media Formulations and Under Different Growth Condition

\begin{tabular}{|c|c|c|c|}
\hline \multicolumn{4}{|l|}{ Molasses concentration } \\
\hline $20 \%$ & $226.4 \pm 11.1$ & $31.3 \pm 2.5$ & $7258.5 \pm 545.9$ \\
\hline $30 \%$ & $209.7 \pm 14.4$ & $47.6 \pm 4.4$ & $4433.1 \pm 407.9$ \\
\hline $50 \%$ & $19.4 \pm 5.8$ & $3.7 \pm 0.4$ & $5266.9 \pm 66.0$ \\
\hline \multicolumn{4}{|l|}{ Spore concentration } \\
\hline $1 \times 10^{4}$ spores $/ \mathrm{ml}$ & $185.3 \pm 9.4$ & $28.9 \pm 0.7$ & $6886.6 \pm 192.0$ \\
\hline $1 \times 10^{5}$ spores $/ \mathrm{ml}$ & $226.7 \pm 21.7$ & $30.2 \pm 2.3$ & $7552.5 \pm 605.9$ \\
\hline 5.5 & $178.2 \pm 11.1$ & $32.7 \pm 1.9$ & $5476.9 \pm 323.9$ \\
\hline 6.5 & $223.0 \pm 21.9$ & $35.4 \pm 2.2$ & $6322.7 \pm 395.9$ \\
\hline 7.5 & $184.9 \pm 13.0$ & $36.6 \pm 2.7$ & $5069.0 \pm 383.9$ \\
\hline 8.5 & $210.3 \pm 1.6$ & $34.9 \pm 3.5$ & $6070.8 \pm 611.9$ \\
\hline \multicolumn{4}{|l|}{ Cultivation temperature } \\
\hline $20^{\circ} \mathrm{C}$ & $101.6 \pm 10.4$ & $20.6 \pm 0.7$ & $4883.0 \pm 144.0$ \\
\hline $25^{\circ} \mathrm{C}$ & $125.0 \pm 14.3$ & $25.4 \pm 2.9$ & $4949.0 \pm 473.9$ \\
\hline $30^{\circ} \mathrm{C}$ & $213.0 \pm 7.9$ & $28.1 \pm 2.8$ & $7618.4 \pm 731.9$ \\
\hline Control(D15[xyn2]) & $255.6 \pm 20.7$ & $35.5 \pm 1.9$ & $7216.6 \pm 401.9$ \\
\hline
\end{tabular}

The values in this table were obtained using six parallel cultures.

temperatures yielded less biomass, accompanied by a significant drop in the $\beta$-xylanase productivity.

The recombinant strain A. niger $\mathrm{D} 15[x y n 2] \mathrm{pyrG}^{-}$is an uridine deficient strain that normally requires the addition of uridine to synthetic growth media. Molasses is derived from crushed sugarcane plant material and therefore contains, apart from sugars, enough other nutrients, including uridine and uridine precursors, to support growth of uridine deficient strains. Although the A. niger D15[xyn2]pyrG ${ }^{-}$strain grew well on molasses without the addition of uridine (Fig. 3a,b), the $\operatorname{pyrG}^{-}$mutation still could have a negative effect on the biomass produced when the uridine or uridine precursors / substitute in the molasses or transport into the cell became limited. Additional pyrG gene copies were integrated into the genome of strain A. niger D15[xyn2]pyrG- (generating strain $A$. niger D15[xyn2]) to complement the pyrG- muta- tion. Strain A.niger D15[xyn2] was compared to A.niger $\mathrm{D} 15\left[\right.$ xyn2]pyrG ${ }^{-}$with regard to $\beta$-xylanase production and productivity (Fig. 3c). The $\beta$-xylanase and biomass production increased with $14 \%$ and $10 \%$, respectively, corresponding to a productivity increase of $3 \%$. These results underline the importance of using prototrophic strains independent of nutrient supplements.

Molasses (76\% dry mass) contains significant amounts of potassium and chlorine [54]. Redkar et al. [32] found that salt adaptation affects gene expression levels. The effect of adapting strain $A$. niger D15[xyn2] to $2 \mathrm{M} \mathrm{KCl}$ on $\beta$-xylanase and biomass production was evaluated. The salt-adapted strain A. niger D15[xyn2]SA gave the highest maximum $\beta$ xylanase activity $(300.8 \mathrm{U} / \mathrm{ml})$ and $\beta$-xylanase productivity (8620.3 U/g dry weight) obtained for any of the recombinant strains (Fig. 2d, Table 3). This represents an improvement of 
more than $30 \%$ on strain A. niger $\mathrm{D} 15[x y n 2] \mathrm{pyrG}^{-}$before the addition of the pyrG gene copies and salt adaptation.

\section{CONCLUSIONS}

This study illustrated the successful overproduction of several cellulases and hemicellulases in A. niger using media rich in fermentable sugars, thus limiting the production of A. niger's native enzymes. Secretion of the enzymes was preferred in order to simplify harvesting of the enzymes. The heterologous enzymes were produced as a significant portion of the total extracellular protein fraction with little additional protein contaminants [31] to simplify downstream process. All enzymes produced high levels of activity and in most cases the characteristic of the heterologous enzymes were similar to that of their native equivalent (Table 3 ).

The use of a $\mathrm{pH}$ mutant of A. niger as host allowed for the production of significant amounts of extracellular proteins without the problem of proteolytic degradation. The $\mathrm{pH}$ of the growth media was monitored throughout the study,

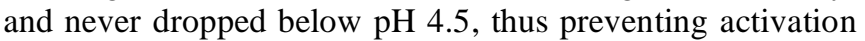
of production of the remaining native $A$. niger extracellular acid proteases. No visible degradation of the recombinant enzymes could be detected by SDS-PAGE. This overproduction of recombinant proteins in the absence of other hydrolases and proteases yields recombinant enzymes at high homogeneity.

The effect of cultivation condition on the heterologous protein production by recombinant Aspergillus strains using molasses as growth medium was also illustrated. The use of the constitutive gpd promoter enabled the strain to produce the recombinant enzymes upon germination without being effected by the sugar concentration in the media [31]. Production of the recombinant enzymes using the gpd promoter does not require the addition of an inducer, thus simplifying the production of recombinant enzymes in bulk.

Optimal conditions for the production of T. reesei Xyn2 $\beta$-xylanase can be summarized as follows: inoculate $20 \%$ molasses at $\mathrm{pH} 6.5$ with a spore inoculum of at least $1 \times 10^{6}$ spores $/ \mathrm{ml}$ and cultivate at a temperature of $30^{\circ} \mathrm{C}$. The importance of using prototrophic recombinant strains that are salt adapted was also demonstrated. Although up-scaling of production of recombinant proteins remain a formidable bioengineering challenge, functional production of several cellulases and hemicellulases to high homogeneity could be demonstrated, paving the way to their large-scale production.

\section{ACKNOWLEDGEMENTS}

We would like to thank Prof. C.A.M.J.J. van den Hondel (TNO, Zeist, The Netherlands) for providing the A. niger D15 strain used as fungal host for this study.

\section{REFERENCES}

[1] Aro N, Pakula T, Penttila M. Transcriptional regulation of plant cell wall degradation by filamentous fungi. FEMS Microbiol Rev 2005; 29: 719-39.

De Vries RP. Regulation of Aspergillus genes encoding plant cell wall polysaccharide-degrading enzymes; relevance for industrial production. Appl Microbiol Biotechnol 2003; 61: 10-20.

[3] De Vries RP, Visser J. Aspergillus enzymes involved in degradation of plant cell wall polysaccharides. Microbiol Mol Biol Rev 2001; 65: 497-522.
Parenicova L, Skouboe P, Samson RA, et al. In: Samson RA, Pitt JI Eds. Integration of modern taxonomic methods for Penicillium and Aspergillus classification. Singapore, Harwood Academic Publishers 2000; 413-24.

Christensen T, Woeldike H, Boel E, et al. High level expression of recombinant gene in Aspergillus oryzae. Biotechnology 1988; 6: 1419-22.

[6] Conesa A, Punt PJ, van den Hondel CAMJJ. Fungal peroxidases: molecular aspects and applications. J Biotechnol 2002; 93: 143-58.

[7] Iwashita K. Recent studies of protein secretion by filamentous fungi. J Biosci Bioeng 2002; 94: 530-5.

[8] Verdoes JC, Punt PJ, van den Hondel CAMJJ. Molecular genetic strain improvement for the overproduction of fungal proteins by filamentous fungi. Appl Microbiol Biotechnol 1995; 43: 195-205.

[9] Archer DB. Filamentous fungi as microbial cell factories for food use. Curr Opin Biotechnol 2000; 11: 478-83.

[10] Gibbs PA, Seviour RJ, Schmid F. Growth of filamentous fungi in submerged culture: problems and possible solutions. Crit Rev Biotechnol 2000; 20: 17-48.

[11] Punt PJ, van Biezen N, Conesa A, et al. Filamentous fungi as cell factories for heterologous protein production. Trends Biotechnol 2002; 20: 200-6.

[12] Radzio R, Kuck U. Synthesis of biotechnologically relevant heterologous proteins in filamentous fungi. Process Biochem 1997; 32: 529-39.

[13] Van den Hombergh JPTW, Van de Vondervoort PJI, FraissinetTachet L, et al. Aspergillus as a host for heterologous protein production: the problem of proteases. Trends Biotechnol 1997; 15: 256-63.

[14] Saxena RK, Malhotra B, Batra A. In: Arora DK, Bridge PD, Bhatnagar D, Eds. Handbook of Fungal Biotechnology: Second edition, Revised and Expanded. New York, Marcel Dekker Inc. 2004; $287-$ 97.

[15] Beg QK, Kapoor M, Mahajan L, et al. Microbial xylanases and their industrial applications: a review. Appl Microbiol Biotechnol 2001; 56: 326-38.

[16] Cherry JR, Fidantsef AL. Directed evolution of industrial enzymes: an update. Curr Opin Biotechnol 2003; 14: 438-43.

[17] Colagrande O, Silva A, Fumi MD. Recent applications of biotechnology in wine production. Biotechnol Prog 1994; 10: 2-18

[18] Oksanen T, Pere J, Paavilainen L, et al. Treatment of recycled kraft pulps with Trichoderma reesei hemicellulases and cellulases. J Biotechnol 2000; 78: 39-48.

[19] Sun Y, Cheng J. Hydrolysis of lignocellulosic materials for ethanol production: a review. Biores Technol 2002; 83: 1-11.

[20] Maat J, Roza M, Verbakel J, et al. In: Visser J, Beldman G, Voragen AGJ, Eds. Xylans and Xylanases. Amsterdam, Elsevier Science Publishers 1992; 349-60.

[21] Beauchemin KA, Morgavi DP, Mcallister TA, et al. In: Garnsworthy PC, Wiseman J, Eds. Recent advances in animal nutrition 2001. Nottingham, Nottingham University Press 2001, 297-322.

[22] Bedford MR. Exogenous enzymes in monogastric nutrition - their current value and future benefits. Anim Feed Sci Technol 2000; 86: $1-13$.

[23] Owens B, Tucker L, Collins MA, McCracken KJ. Effects of different feed additives alone or in combination on broiler performance, gut microflora and ileal histology. Br Poult Sci 2008; 49: 202-12.

[24] Bajpai P. Biological bleaching of chemical pulps. Crit Rev Biotechnol 2004; 24: 1-58.

[25] Jayani RS, Saxena S, Gupta R. Microbial pectinolytic enzymes: A review. Proc Biochem 2005; 40: 2931-44.

[26] Aly AS, Moustafa AB, Hebeish A. Bio-technological treatment of cellulosic textiles. J Cleaner Produc 2004; 12: 697-705.

[27] McIntyre M, Breum J, Arnau J, et al. Growth physiology and dimorphism of Mucor circinelloides (syn. racemosus) during submerged batch cultivation. Appl Microbiol Biotechnol 2002; 58: 495-502.

[28] Herrera S. Industrial biotechnology - a chance at redemption. Nat Biotechnol 2004; 22: 671-6.

[29] Jafelice LR, Wiseman A, Goldfarb PS. Production of lignin peroxidase by Phanerochaete chrysoporium in medium containing molasses. Biochem Soc Trans 1990; 18: 642-3.

[30] Vitolo M, Duranti MA, Pellegrim MB. Effect of $\mathrm{pH}$, aeration and sucrose feeding on the invertase activity of intact $S$. cerevisiae cells grown in sugarcane blackstrap molasses. J Ind Microbiol 1995; 15: 76-9. 
[31] Rose SH, Van Zyl WH. Constitutive expression of the Trichoderma reesei $\beta-1,4$-xylanase gene (xyn2) and the $\beta$-1,4-endoglucanase gene (egI) in Aspergillus niger in molasses and defined glucose media. Appl Microbiol Biotechnol 2002; 58: 461-8.

[32] Redkar RJ, Herzog RW, Singh NK. Transcriptional activation of the Aspergillus nidulans gpdA promoter by osmotic signals. Appl Environ Microbiol 1998; 64: 2229-31.

[33] Wiebe MG, Karandikar A, Robson GD, et al. Production of tissue plasminogen activator (t-PA) in Aspergillus niger. Biotechnol Bioeng 2001; 76: 164-74.

[34] Plüddemann A, Van Zyl WH. Evaluation of Aspergillus niger as host for virus-like particle production, using the hepatitis B surface antigen as a model. Curr Genet 2003; 43: 439-46.

[35] Bailey MJ, Biely P, Poutanen K. Interlaboratory testing of methods for assay of xylanase activity. J Biotechnol 1992; 23: 257-70.

[36] Miller GL, Blum R, Glennon WE, et al. Measurement of carboxymethylcellulase activity. Anal Biochem 1960; 2: 127-32.

[37] Van Hartingsveldt W, Mattern IE, van Zeijl CM, et al. Development of a homologous transformation system for Aspergillus niger based on the pyrG gene. Mol Gen Genet 1987; 206: 71-6.

[38] Mattern IE, van Noort JM, van den BP, et al. Isolation and characterization of mutants of Aspergillus niger deficient in extracellular proteases. Mol Gen Genet 1992; 234: 332-6.

[39] Gordon CL, Archer DB, Jeenes DJ, et al. A glucoamylase: : GFP gene fusion to study protein secretion by individual hyphae of Aspergillus niger. J Microbiol Methods 2000; 42: 39-48.

[40] La Grange DC, Pretorius IS, Van Zyl WH. Expression of a Trichoderma reesei $\beta$-xylanase gene $(X Y N 2)$ in Saccharomyces cerevisiae. Appl Environ Microbiol 1996; 62: 1036-44.

[41] Setati ME, Ademark P, Van Zyl WH, et al. Expression of the Aspergillus aculeatus endo- $\beta$-1,4-mannanase encoding gene (manl) in Saccharomyces cerevisiae and characterisation of the recombinant enzyme. Protein Expr Purif 2001; 21: 105-14.

[42] Montenecourt BS. Trichoderma reesei cellulases. Trends Biotechnol 1983; 1: 156-60.

[43] Takashima S, Iikura H, Nakamura A, et al. Overproduction of recombinant Trichoderma reesei cellulases by Aspergillus oryzae and their enzymatic properties. J Biotechnol 1998; 65: 163-71.

[44] Zurbriggen BD, Penttila ME, Viikari L, Bailey MJ. Pilot scale production of a Trichoderma reesei endo-beta-glucanase by brewer's yeast. J Biotechnol 1991; 17: 133-46.
[45] Kleywegt GJ, Zou JY, Divne C, et al. The crystal structure of the catalytic core domain of endoglucanase I from Trichoderma reesei at $3.6 \AA$ resolution, and a comparison with related enzymes. J Mol Biol 1997; 272: 383-97.

[46] Okada H, Tada K, Sekiya T, et al. Molecular characterization and heterologous expression of the gene encoding a low-molecularmass endoglucanase from Trichoderma reesei QM9414. Appl Environ Microbiol 1998; 64: 555-63.

[47] Bailey MJ, Siika-aho M, Valkeajärvi A, et al. Hydrolytic properties of two cellulases of Trichoderma reesei expressed in yeast. Biotechnol Appl Biochem 1993; 17: 65-76.

[48] Törrönen A, Rouvinen J. Structural comparison of two major endo1,4-xylanases from Trichoderma reesei. Biochemistry 1995; 34: 847-56.

[49] Dekker RFH. Bioconversion of hemicellulose: Aspects of hemicellulase production by Trichoderma reesei QM 9414 and enzymatic saccharification of hemicellulose. Biotechnol Bioeng 1983; 25: 1127-46.

[50] Lappalainen A, Siika-aho M, Kalkkinen N, et al. Endoxylanase II from Trichoderma reesei has several isoforms with different isoelectric points. Biotechnol Appl Biochem 2000; 31: 61-8.

[51] Crous JM, Pretorius IS, Van Zyl WH. Cloning and expression of an Aspergillus kawachii endo-1,4- $\beta$-xylanase gene in Saccharomyces cerevisiae. Curr Genet 1995; 28: 467-73.

[52] Ito K, Ikemasu T, Ishikawa T. Cloning and sequencing of the $x y n A$ gene encoding xylanase A of Aspergillus kawachii. Biosci Biotechnol Biochem 1992; 56: 906-12.

[53] Lynd LR, Wyman CE, Gerngross TU. Biocommodity Engineering. Biotechnol Prog 1999; 15: 777-93.

[54] Van Niekerk BDH. Byproducts of the sugar industry as animal feeds. S Afr J Anim Sci 1981; 11: 119-37.

[55] Karaffa L, Kubicek CP. Aspergillus niger citric acid accumulation: do we understand this well working black box? Appl Microbiol Biotechnol 2003; 61: 189-96.

[56] Peberdy JF. Protein secretion in filamentous fungi - trying to understand a highly productive black box. Trends Biotechnol 1994; 12: $50-7$.

[57] Mackenzie DA, Gendron LC, Jeenes DJ, et al. Physiological optimization of secreted protein production by Aspergillus niger. Enzyme Microb Technol 1994; 16: 276-80.

(C) Rose and van Zyl; Licensee Bentham Open.

This is an open access article distributed under the terms of the Creative Commons Attribution License (http: //creativecommons.org/licenses/by/2.5/), which permits unrestrictive use, distribution, and reproduction in any medium, provided the original work is properly cited. 